\title{
THE MODERATING ROLE OF FIRM SIZE ON FINANCIAL CHARACTERISTICS AND ISLAMIC FIRM VALUE AT INDONESIAN EQUITY MARKET
}

\author{
Perdana Wahyu SANTOSA (10* \\ YARSI University, Jakarta, Indonesia
}

Received 29 February 2020; accepted 21 April 2020

\begin{abstract}
This study aims to understand the moderating role of firm size on financial characteristics and Islamic firm value. Then study how the influence of firm size moderation on the relationship of financial characteristics and corporate governance with firm value. This study uses secondary data from financial statements and analyzed by the panel data method for six years. The sample selection is arranged by the purposive sampling method with Islamic index constituent population. Conclusion: leverage, profitability, and efficiency have a significant positive effect on Islamic firm value, but the liquidity and audit committee do not affect. Firm size moderators provide a reinforcing effect for all independent variables so that liquidity and audit committees have a positive effect on firm value. Implications: Islamic firm investors in the equity market should consider the crucial variable, namely firm size, in addition to firm and corporate governance characteristics. These conclusions provide important implications for managers and relevant authorities to enhance financial market information related to firm value and further attention to corporate governance mechanisms.
\end{abstract}

Keywords: firm value, financial characteristics, audit committee, firm size, equity market, Islamic index.

JEL Classification: G30, G32.

\section{Introduction}

Financial information, especially firm value in Islamic financial market, plays an essential role in many types of decisions, made their stakeholders mostly equity investors (Santosa, 2020). However, the critical of decisions taken based on this analysis depends, among other things, on the quality of accounting information and market transparency (Abdul-Majid, 2017). Decision making will be useful as equity information needs to be an accurate, relevant, and reliable, mainly fair view of a firm value or financial performance and corporate governance considerations. The financial performance such as liquidity, leverage, profitability, and efficiency are core variable to predict the firm value, besides corporate governance as a control variable and firm size as moderating variable, theoretically. However, real-life situations require some flexibility in understanding the financial performance information that optimizes return to investments in the Indonesian Islamic equity market (Černius \& Birškytė, 2020; Santosa, 2019).

The movement of the Islamic equity index during the last five years has increased significantly, which is 2014 the
Islamic index was recorded at 691.04. Although the Islamic index had decreased by 87.69 in 2015, in 2016, the index experienced a reversal and again increased consistently until 2018. Indonesia stock exchange recorded growth in value and frequency of sharia-based stock transactions in the 2011-2016 period higher than non-sharia shares. The average growth in the volume of sharia stock transactions 167.2 percent compared to 130 percent non-sharia. Whereas, in terms of the average growth of sharia stock transaction value in the last five years, it reached 70.7 percent compared to 25.4 percent non-sharia. The average frequency of transaction growth reached 185.7 percent compared to 160.7 percent non-sharia equity (Indonesia Stock Exchange, 2018).

The fluctuations of the Islamic index is undoubtedly influenced by some important variables such as firm characteristics, firm size, corporate governance, and macrorisk environments (Santosa, 2019). Some previous studies recorded those firm characteristics according to financial information in the performance of some main variables such as liquidity, leverage (solvency), profitability, activity,

${ }^{*}$ Corresponding author. E-mail: perdana.wahyu@yarsi.ac.id 
and corporate governance are concluded to influence direct/indirect to Islamic firm value. The question arises to what extent such firm size as the moderating variable is significant and has an effect on the financial decisions of the Islamic firm. If it is found that interactions between firm size and main variables are significant and strengthen or weaken to right managerial decisions, it becomes crucial to find the most interplay to this problem (Tambunan et al., 2017; Hunjra, 2018; Shao, 2019; Santosa, 2010). The issue of Islamic firm value is more crucial for the large firm because there exist big collateral assets and the corporate governance mechanism on how to minimize the impact of quality financial statements and audit opinion (Nurlela et al., 2019).

The study aims to determine to what main and specific financial ratios such as liquidity, leverage, profitability, efficiency, and audit committee factors affect Islamic firm value that role of moderating firm size as the basis for financial decision making, including financing, investment, and operating decisions. Using the data panel model reveals that significant main variables effect on firm value with audit committee as controlling variable and the interaction between main variables with moderating of firm size, simultaneously. The effects of interaction between firm size as moderating with some primary financial ratios are valuable information for investors to make the decision.

\section{Literature and hypothesis}

The effect of liquidity on Islamic firm value is still a debate where there are parties supported by in-depth studies stating that liquidity has a significant effect on firm value (Febriawan \& Santosa, 2018; Marsha \& Murtaqi, 2017). However, it differs from a study related to liquidity and firm value insignificantly effect (Nurhayati, 2013). Theoretically, low liquidity indicates high operational risk, while high current ratios indicate excess current assets, which will negatively affect company profitability (Ross, Westerfield, \& Jordan, 2013) numerous studies analyze the relationship between profitability and the firm value indicates a research gap between them. Several previous studies have concluded that profitability (ROA/ROE) does significant effect on firm value (Utami \& Welas, 2019; Santosa, 2019). However, Thaharah and Asyik (2016) stated that profitability does not significantly influence firm value. Increased profitability, of course, increases the company's internal equity so that firms can grow and guarantee cash dividends for shareholders. The efficiency of assets management to create sales has a positive impact on business expansion and firm value, and this fact supported several previous studies such as Santosa (2010) and Nguyen et al. (2019). They revealed that efficiency (TATO) had a significant effect on firm value. However, it is different from the conclusions of (Utami \& Welas, 2019), which state that efficiency does not affect firm value. More efficient management shows the success of a company's business in managing company assets (Brigham \& Houston, 2016).
This study needs variable importance to control for a broad set firm characteristic variables that proven to affect firm value. Some previous research have concluded that audit committees and audit quality does significant effect on firm value (Laily, 2017; Sugiarto \& Santosa, 2018; Balagobei, 2018). However, Akinleye, Olarewaju, and Fajuyagbe (2019) stated that the audit committee does not effect on firm value. The audit committee will play a useful role in increasing the credibility of financial statements and help the board of commissioners builds the trust of shareholders to fulfill the obligation to submit information so that the audit committee expected to be able to increase the value of the company and help the implementation of GCG properly to minimize agency cost (Subramanyam, 2014).

This study used the role of moderating firm size because the importance of those proxies varies with the classification techniques panel data applied, to know how the effect of moderating firm size on the relationship between independent and control variables with Islamic firm value. Firm size was chosen because it is an essential variable in some studies about firm performances (Rehman, 2016; Marsha \& Murtaqi, 2017). Beside the influence firm size as moderating role on another variable, a large growing perception determines the firm size also directly significant effect on firm value because firm size relates positively with business diversification, long sustainability, dividend policy stability, and low default risk (Kuhlmann \& Rojahn, 2017; Johan et al., 2012).

\subsection{Effect of liquidity on Islamic firm value}

According to Alamanda and Santosa (2013), the relationship between liquidity and firm value in a corporation is in-line with the theory of the firm, in which relationship tends to be negatively related to risk and return correlation from a business view. The relation between firm value with liquidity means that investment decisions and managerial functions are viewed by two different priorities (Brigham \& Houston, 2016; Kasmiati \& Santosa, 2019). The liquidity that measures the company's ability to pay short-term liabilities is essential for working capital. However, the investor has a negative perception of the firm if over-liquidity, primarily caused by inventory problems (Santosa, 2019). Based on some previous research, such as Nurhayati (2013), Sugiarto and Santosa (2018) and Sutriani (2014) concluded that the relationship between liquidity and the firm value was negatively significant. Based on the explanations above, the hypotheses of this study are:

H1a: Liquidity negatively affects Islamic firm value (-).

H1b: Liquidity negatively affects Islamic firm value moderating by firm size (-).

\subsection{Effect of leverage on Islamic firm value}

Brigham and Houston (2016) stated that the leverage reflects the company's ability to meet its long-term debt as indicated by the proportion of equity capital to cover off 
debt. In assessing a company, investors will look at the level of debt in order to assess the extent to which the company uses the money it has borrowed (Cheng \& Tzeng, 2011). The level of the company's debt can also indicate whether the financial company is healthy or not, which is that excessive debt generally creates financial distress problems. The use of debt in a reasonable and controlled ratio has the potential to increase business and firm value so that it becomes a positive signal for investo (Suwardika \& Mustanda, 2017; Santosa \& Laksana, 2011). Based on these explanations, the hypothesis of this study are:

H2a: Leverage positively affects Islamic firm value (+).

$\mathrm{H} 2 \mathrm{~b}$ : Leverage positively affects Islamic firm value moderating by firm size $(+)$.

\subsection{Effect of profitability on Islamic firm value}

According to Brigham and Houston (2016) profitability is the company's ability to generate profits with all assets owned by the company. Profitability reflects the company's return from all assets (funding) provided to the company. High profits will cause demand for shares to increase so that stock prices will rise and result in returns obtained by investors also increase so that it can also increase the value of the company (Masdupi, Tasman, \& Davista, 2018; Santosa \& Laksana, 2011). This conclusion means companies that have high profits have a positive impact on investors and companies because investors believe in companies that have high profits to invest (Nurlela et al., 2019; Farah Freihat, 2019). Based on these explanations, the hypotheses of this study are:

$\mathrm{H3a}$ : Profitability positively influences Islamic firm value $(+)$.

$\mathrm{H} 3 \mathrm{~b}$ : Profitability positively influences Islamic firm value moderating by firm value $(+)$.

\subsection{Effect of efficiency on Islamic firm value}

According to Santosa (2019) level of efficiency of the company assets in generating sales volumes measures with total assets turnover in managing total assets. Some aspects of activity analysis correlate with liquidity and focus on the effectiveness of management in managing two groups of specific assets - accounts receivable and inventory - and total assets as a whole, known as asset turnover (Ross et al., 2013). Taking the consideration into activity ratio, we get in-depth information is obtained about the company's operations. The higher of efficiency ratio, the smaller the investment needed to generate sales and, thus, more profitable for the company (Sugiarto \& Santosa, 2018). These findings supported previous research that was conducted by Nanik and Candra (2016), Sugiarto and Santosa (2018), Apan and İslamoğlu (2018), and Santosa (2010), which say that efficiency does effect on firm value, significantly. Based on these explanations, the research hypothesis are:

H4a: Efficiency positively affects Islamic firm value (+).

H4b: Efficiency positively affects Islamic firm value moderating by firm size $(+)$.

\subsection{The influence of audit committee on Islamic firm value}

With the audit committee's understanding of the problem and risks, it can minimize the potential for loss and fraud. Furthermore, with the audit committee's understanding of the company's internal control system, it is expected to detect and prevent various acts of fraud and opportunistic management behavior that can harm the company so that the presence of the audit committee expected the increase firm value (N. Van Tuan \& N. A. Tuan, 2016; Abdul-Majid, 2017). Some previous research findings also support the above statement in which the relationship of corporate governance or audit committee with company values is positive (Thaharah \& Asyik, 2016; Mukhtaruddin et al., 2019). Based on these explanations, the research hypothesis:

H5a: The Audit committee positively influences Islamic firm value $(+)$.

H5b: The Audit committee positively influences Islamic firm value moderating by firm size $(+)$.

\subsection{Effect of firm size on Islamic firm value}

Company size has a significant influence on company performance and company value both directly and indirectly because it does not only have an impact on the company's characteristics but also affects the company's image and goodwill (Brigham \& Houston, 2016; Thaharah \& Asyik, 2016; Santosa, 2019). Some previous studies conclude that firm size has a positive effect on firm value with several considerations such as diversification, product and service portfolio, collateral, business cycle, company age, company image and capital structure (Santosa, 2019; Prieto \& Lee, 2019).

H6a: Firm size positively affects Islamic firm value (+).

H6b: Firm size moderates the effect of liquidity, leverage, profitability, efficiency, and audit committee on Islamic firm value $(+/-)$.

\subsection{Frameworks}

From the theoretical review and the hypothesis development, the variables in this study are liquidity, leverage, profitability, and activity as an independent variable and the Audit Committee as a controlling variable with firm size as moderating variables and firm value as the dependent variable. So the research mindset that formed is as follows (Kasmiati \& Santosa, 2019; Tartilla, Darmansyah, \& Anwar, 2018; Santosa, 2019):

Figure 1 decsribes the main independent variables are liquidity, leverage, profitability and activity (efficiency) ratios are directly effect on Islamic firm value with the controlling variable and moderating variable of audit committee and firm size respectively. This framework was classified into two models (1) all variable effect (four main variables; controlling and moderating variables) on firm value; (2) all variable effect on firm value with the interaction of moderating firm size and four main independent variables. 


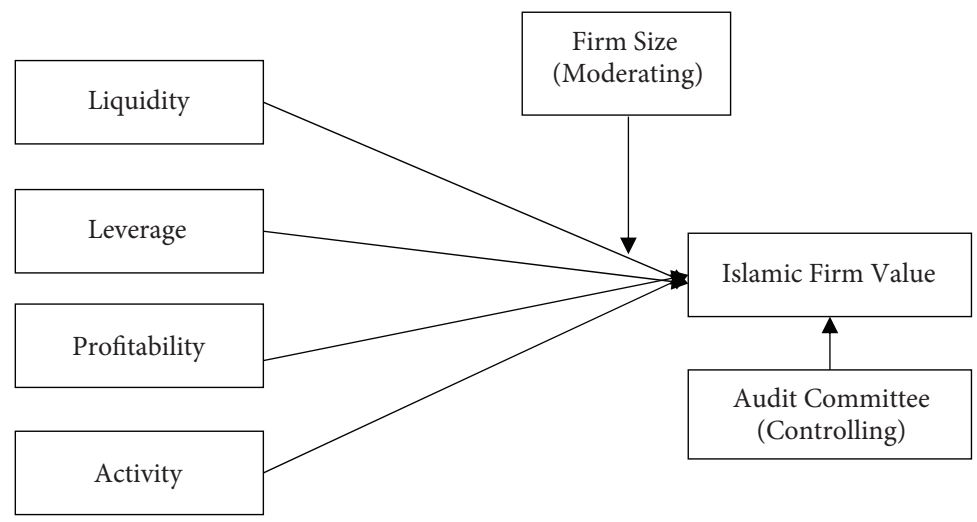

Figure 1. Research framework of variables

\section{Data and method}

\subsection{Data}

In this study, the type of data used is secondary data sourced from the Indonesia Stock Exchange (IDX) through the official website www.idx.co.id; The Indonesia Capital Market Institute (TICMI) data center, the Indonesian Capital Market Directory (ICMD), and financial report that was released by the Islamic firm periodically. The data collection technique in this study is documentation using written materials or data made by other parties by viewing, analyzing, and quoting published notes about sample companies listed in the Indonesian Sharia Stock Index (ISSI) on 2013-2018.

\subsection{Population and sampling}

According to the aims of this study, the population is the ISSI that has specific numbers and characteristics of Islamic firms, which as constituents of the ISSI index on the Indonesia Stock Exchange. The population in this study were all 331 companies which are constituent of ISSI that listed in Indonesia Stock Exchange on 2013 to 2018 period. Almost $41.2 \%$ (110 Islamic firms) of the ISSI constituents are in-out according to DSN in this period. The sampling technique is done by a purposive sampling method that is a sampling technique with specific criteria and considerations (Santosa \& Hidayat, 2014)). The study determined that the criteria to be the sample in this study are as present in Table 1.

Table 1. Sampling criteria

\begin{tabular}{|c|l|c|}
\hline No & \multicolumn{1}{|c|}{ Keterangan } & Jumlah \\
\hline 1 & The firms as a constituent of the ISSI index & 267 \\
\hline 2 & The firms as an in-constituent of the ISSI index & $(135)$ \\
\hline 3 & $\begin{array}{l}\text { The firms have not released the financial report } \\
\text { in IDR (auditted) }\end{array}$ & $(12)$ \\
\hline 4 & $\begin{array}{l}\text { Companies with an audit committee below 3 } \\
\text { (three) and members do not have accounting } \\
\text { or financial competencies> 1 (one) }\end{array}$ & $(10)$ \\
\hline Number of samples (with complete data) & 110 \\
\hline Research period (Quarterly): 2013-2018 & 24 \\
\hline Observations (N) & 2.640 \\
\hline
\end{tabular}

\subsection{Model data panel}

According to Gujarati and Porter (2013), panel data regression is a regression technique that combines time series data with cross data. The panel data will be analyzed using Eviews 10 software, a program used to process statistical and econometric data in the form of time series, cross-sections, and panel data.

This study conducted using a panel data regression model with the following equation (Hermawan, 2011; Widyastuti, 2019; Sugiarto \& Santosa, 2018; Santosa, 2019; Marsha \& Ghozali, 2017; Carter, Simkins, \& Simpson, 2003):

Model 1:

$$
\begin{aligned}
& F V_{i t}=\alpha_{0}+\alpha_{1} L Q_{i t}+\alpha_{2} L V_{i t}+\alpha_{3} P R_{i t}+ \\
& \alpha_{4} A C_{i t}+\alpha_{5} C A_{i t}+\alpha_{6} S Z+\varepsilon_{i t} .
\end{aligned}
$$

\section{Model 2:}

$$
\begin{aligned}
& F V_{i t}=\delta_{0}+\delta_{1} L Q_{i t}+\delta_{2} L V_{i t}+\delta_{3} P R_{i t}+ \\
& \delta_{4} A C_{i t}+\delta_{5} C A_{i t}+\delta_{6}(L Q \cdot S Z)_{i t}+\alpha_{7}(L V \cdot S Z)_{i t}+ \\
& \delta_{8}(P R \cdot S Z)_{i t}+\delta_{9}(A C \cdot S Z)_{i t}+\varepsilon_{i t},
\end{aligned}
$$

where: $F V=$ Tobin's $\mathrm{Q} ; L Q=$ Current ratio at the end of the prior year; $L V=$ Debt-to-equity ratio at the end of the prior quarter. $P R=$ Return on assets at the end of the prior quarter. $A C=$ Activity/efficiency ratio at the end of the prior quarter; $C A=$ Committee audit at the end of the prior quarter; $S Z=$ Natural logarithm of total assets at the end of the prior quarter. The dependent variable is Tobin's $Q$, which good indicator that reflects long-term financial performance and business opportunity. Moreover, the reason Tobin's $Q$ can be a proxy of firm value is that it can be deemed as the amount in monetary units. Tobin's $Q$ is regarded as a better measure than accounting returns and minimizes the risk of accounting distortion. Besides, it reflects the total firm value, including market value (capitalization), total assets, and debt.

\subsection{Variables description}

Four types of variables are involved in this study, namely dependent variable (firm value), dependent variables (liquidity, leverage, profitability, and activity), control 
variable (audit committee), and moderating variable (firm size). The variables used in this study are described, as shown in Table 2 below.

Table 2. Variables description

\begin{tabular}{|l|c|l|l|}
\hline \multicolumn{1}{|c|}{ Variable } & Notation & Measurement & Scale \\
\hline Dependent: & FV & $\begin{array}{l}\text { Market capitalization + total } \\
\text { debts to total assets }\end{array}$ & Ratio \\
\hline Firm Value & LQ & $\begin{array}{l}\text { Current assets to current } \\
\text { liabilities }\end{array}$ & Ratio \\
\hline Independent: & LV & Total debt to equity & Ratio \\
\hline Liquidity & PR & Net income to total assets & Ratio \\
\hline Leverage & AC & Net sales to total assets \\
\hline Profitability & CA & $\begin{array}{l}\text { Number of commitee } \\
\text { auditor }\end{array}$ & Ratio \\
\hline Activity & Control variable: & $\begin{array}{l}\text { Natural logarithm of total } \\
\text { assets }\end{array}$ \\
\hline $\begin{array}{l}\text { Audit } \\
\text { commitee }\end{array}$ & SZ & \\
\hline Moderating variable: & Firm size & Sul & \\
\hline
\end{tabular}

\section{Results and discussions}

\subsection{Descriptive statistics}

Based on the descriptive results, the following sample characteristics displayed in this study include sample average (mean), the maximum value (max), minimum value (min), and standard deviation for each variable. Table 3 shows a descriptive analysis of the ISSI index constituent sample data quarterly for the period 2013-2018:

In general, the results of the descriptive analysis show relatively good data and normally distributed. There is no extreme data used for this study to provide comprehensive data.
Table 3. Results of descriptive statistics

\begin{tabular}{|l|c|c|c|c|}
\hline \multicolumn{1}{|c|}{ Variabel } & Mean & Max & Min & Std. Dev. \\
\hline Tobin's Q & 4.8406 & 32.5400 & 0.5500 & 6.5005 \\
\hline Liquidity & 0.2648 & 0.6933 & 0.6856 & 0.1552 \\
\hline Leverage & 0.7829 & 2.6500 & 0.1500 & 0.5741 \\
\hline Profitability & 0.1209 & 0.4918 & 1.5148 & 8.7737 \\
\hline Activity & 0.8707 & 2.4209 & 0.1782 & 0.6484 \\
\hline $\begin{array}{l}\text { Audit } \\
\text { commitee }\end{array}$ & 3.3384 & 7.0000 & 3.0000 & 0.6909 \\
\hline Firm size & 24.3663 & 30.8810 & 17.2803 & 12.7155 \\
\hline
\end{tabular}

\subsection{Panel data analysis model estimation}

\section{Panel data estimation: Model 1}

Panel model 1 and model 2 show the findings that are interesting. Data analysis used software Eviews-10 was showed the results, as shown in Table 3 to Table 7, respectively. In general, the analysis results are in-line with the prediction before. One of the most interesting of these results is the influence of moderating by firm size showed influence to independent variables, significantly. Each finding of the hypothesis will be explained at discussion section more deeply below.

The Table 4 covers the period 2013-2018 in quarterly and includes the Islamic firms that listed in Indonesia Sharia Stock Index (ISSI) at Indonesia Stock Exchange. This study excluded the unaudited financial statement and missing data or not applicable observations. Dependent variable: Islamic firm value; explanatories: liquidity: current ratio; leverage: debt to equity ratio; profitability: return on assets; activity: sales to total assets; controlling: audit committee: number of auditor; and moderating: firm size: natural logarithm of total assets (as explanatory).

Table 4. The results of panel data Model 1

\begin{tabular}{|l|c|c|c|c|c|c|c|}
\hline & & \multicolumn{2}{|c|}{ CEM } & \multicolumn{2}{c|}{ FEM } & \multicolumn{2}{c|}{ REM } \\
\hline Variables & Predict & Coeff & Sig & Coeff & Sig & Coeff & Sig \\
\hline Liquidity & - & 0.0046 & 0.1208 & 0.0031 & 0.1085 & 0.0029 & $0.0649^{*}$ \\
\hline Leverage & +- & 2.2889 & 0.0071 & 3.2663 & 0.0029 & 2.2834 & 0.0005 \\
\hline Profitability & + & 0.4763 & 0.0000 & 0.2132 & 0.0105 & 0.4641 & 0.0048 \\
\hline Activity & + & 3.0335 & 0.0002 & 2.0428 & 0.0030 & 2.9968 & 0.0033 \\
\hline Audit comm. & + & -1.0515 & 0.0101 & 0.0522 & 0.3273 & -1.0549 & $0.0613^{*}$ \\
\hline Firm size & + & 0.3381 & 0.0322 & 0.5521 & 0.0365 & 0.6822 & 0.0452 \\
\hline C & & -2.3278 & 0.1734 & -3.9812 & 0.8333 & -3.8764 & 0.6821 \\
\hline$R^{2}$ & & 0.6837 & & 0.6913 & & 0.7887 & \\
\hline Adj R & & 0.6623 & & 0.6702 & & 0.7792 & 51.391 \\
\hline F-statistic & & 80.391 & & 42.797 & & & 0.0000 \\
\hline Prob F-stat & & 0.0000 & & 0.0000 & & 0.5817 & \\
\hline D-W & 0.5758 & & 1.3222 & & \\
\hline
\end{tabular}

Note: ${ }^{\star}$ significant at $\alpha=10 \%$. 


\section{Likelihood-test}

To choose the better panel data estimation model between CEM or REM, a Likelihood-test is performed. The hypothesis used is:

$\mathrm{H}_{0}$ : Common Effect Model

Ha: Random Effect Model

Decision:

If the probability of Chi-square $>0.05$ then $\mathrm{H}_{0}$ is accepted.

If the probability of Chi-square $<0.05$ then $\mathrm{H}_{0}$ is rejected.

Table 5. Likelihood-test

\begin{tabular}{|l|c|c|c|}
\hline \multicolumn{1}{|c|}{ Effects Test } & Statistic & d.f. & Prob. \\
\hline Cross-section F & 6.9567 & $(11.46)$ & 0.0000 \\
\hline Cross-section $\mathrm{Chi}^{2}$ & 60.836 & 12 & 0.0000 \\
\hline
\end{tabular}

The Likelihood-test test results in Table 5 show that the probability value of the Chi-square value is 0.0000 . Because the probability value of Chi-square is less than 0.05 , then $\mathrm{H}_{0}$ is rejected so that it can be concluded based on the results of the Likelihood-test better panel data estimation model is REM than CEM.

\section{Chow-test}

Chow testing to determine which model is better between CEM or FEM

The hypothesis test:

Ho: Common Effect Model

Ha: Fixed Effect Model

Decision making:

If the probability of the Chi-square value $>0.05$, then Ho is accepted.

If the probability of the Chi-square value $<0.05$, then Ho is rejected.

Table 6. Results of Chow-Test

\begin{tabular}{|l|c|c|c|}
\hline \multicolumn{1}{|c|}{ Effects Test } & Statistic & d.f. & Prob. \\
\hline Cross-section F & 15.7250 & $(11,405)$ & 0.0000 \\
\hline Cross-section $\mathrm{Chi}^{2}$ & 153.0013 & 12 & 0.0000 \\
\hline
\end{tabular}

Table 6 shows that the Chi-square probability value is 0.0000 and which is smaller than 0.05 then Ho is rejected. Thus the Chow-test determines that the panel estimation model: FEM.

\section{Hausman-test}

The Chow-test above shows that FEM is a better model than REM, this study used Hausman testing to compare between FEM and REM. The hypothesis uses:

Ho: Random Effect Model

Ha: Fixed Effect Model

Decision making:

If the probability of the Chi-square value $>0.05$, then Ho is accepted.

If the probability of the Chi-square value $<0.05$, then Ho is rejected.

Table 7. Hausman-test result

\begin{tabular}{|l|c|c|l|}
\hline Test Summary & Chi-Sq. Statistic & Chi-Sq. d.f. & Prob \\
\hline Cross-section random & 31.9895 & 5 & 0.0032 \\
\hline
\end{tabular}

Table 7 shows the results of the Hausman-test that the probability value of the Chi-square of 0.0032 , which is smaller than 0.05 , then Ho is rejected. The conclude of Likelihood test, Chow test and Hausman test states that model FEM is better than CEM and REM, respectively. The analysis stated that FEM model is the best model for this research.

\section{Panel data estimation: Model 2}

Table 8 presents the data panel results for the regression Model 2, which analyses the main explanatory, controlling, and moderating variables and interaction between main explanatory with a moderating variable to determine the effect on dependent variable, Islamic firm value. In general, the results of Model 2 shown in the table below are similar to the results from Model 1, but this table presents the results of moderating firm size to the main variables.

Table 8 covers the period 2013-2018 in quarterly and includes the Islamic firms that listed in Indonesia Sharia Stock Index (ISSI) at Indonesia Stock Exchange. This study

Table 8. The results of Panel Data Model 2

\begin{tabular}{|l|c|c|c|c|c|c|c|}
\hline & & \multicolumn{2}{|c|}{ CEM } & \multicolumn{3}{c|}{ FEM } & \multicolumn{3}{c|}{ REM Sig } \\
\hline Variables & Predict & Coeff & Sig & Coeff & Sig & Coeff & 0.0029 \\
\hline Liquidity & - & 0.0361 & 0.0338 & 0.0201 & $0.0612^{*}$ & 0.0649 \\
\hline Leverage & +- & 1.3314 & $0.0556^{\star}$ & 3.4163 & 0.0081 & 2.2834 & 0.0000 \\
\hline Profitability & + & 0.5913 & 0.0473 & 0.6232 & 0.0353 & 0.4641 & 0.0000 \\
\hline Activity & + & 2.7735 & $0.0681^{\star}$ & 1.3228 & $0.0562^{*}$ & 2.9968 & 0.0000 \\
\hline Audit comm. & + & 0.7215 & 0.0382 & 0.0812 & $0.0816^{*}$ & -0.1349 & 0.0032 \\
\hline Firm size & + & 0.2841 & 0.0048 & 0.2761 & 0.0237 & 0.4282 & $0.0644^{*}$ \\
\hline C & & -1.3278 & 0.1834 & -2.9012 & 0.6353 & -2.6164 & 0.4021 \\
\hline Liq-Size & + & 0.2629 & 0.0472 & 0.4452 & $0.0732^{*}$ & 0.2538 & 0.0362 \\
\hline
\end{tabular}




\begin{tabular}{|l|c|c|c|c|c|c|c|}
\hline Lev-Size & + & 1.3512 & 0.0412 & 1.8364 & 0.0326 & 1.1248 & 0.0442 \\
\hline Pro-Size & + & 0.1239 & $0.0524^{*}$ & 0.1165 & 0.0353 & 0.1772 & $0.0528^{*}$ \\
\hline Act-Size & + & 0.0553 & 0.0366 & 0.0248 & 0.0481 & 0.0372 & 0.0397 \\
\hline $\mathrm{R}^{2}$ & & 0.6638 & & 0.7802 & & 0.6922 & \\
\hline Adj R & & 0.6441 & & 0.7562 & & 0.6727 & \\
\hline F-statistic & & 69.358 & & 45.512 & & 73.882 & \\
\hline Prob F-stat & & 0.0000 & & 0.0000 & & 0.0000 & \\
\hline D-W & & 0.5932 & & 2.0391 & & 0.8832 & \\
\hline
\end{tabular}

Note: *significant at $\alpha=10 \%$.

excluded the unaudited financial statement and missing data or not applicable observations. Dependent variable: Islamic firm value; explanatories: liquidity: current ratio; leverage: debt to equity ratio; profitability: return on assets; activity: sales to total assets; controlling: audit committee: number of auditor; and moderating: firm size: natural logarithm of total assets (as moderating)-Liq.Size, Lev.Size, Pro-Size and Act-Size is the interaction between variable of liquidity, leverage, profitability, and activity with firm size, respectively. This table covers the period 2013-2018 in quarterly. Financial statement firms and missing data or not applicable observations are not be used.

In general, Model 2 analysis shows a significant positive effect of moderating firm size variables, where all independent variables respond positively. Even the liquidity variable experiences a reversal in the direction of the relationship with the value of the company where previously moderated shows the negative coefficient turns positive. The moderation of firm size results above strengthens the effect of all independent and controlling variables on firm value.

\section{Discussion}

\subsection{Effect of liquidity on Islamic firm value}

The first hypothesis states that liquidity does not affect firm value. Based on the results of the research conducted, the liquidity coefficient value obtained is 0.0031 with a probability of 0.1085 , which means that liquidity has a positive relationship with firm value but does not have a significant effect, so the first hypothesis is accepted. However, after being moderated by firm size, the effect of liquidity on firm value becomes significant at $\alpha=10 \%$.

These findings indicate that if liquidity has increased, it does not affect the value of the company. One reason is excess liquidity and tends to be idle cash illustrating that management is less capable in managing company funds (Paul, Guermat, \& Devi, 2018). Another thing is that the increase in liquidity can be caused by the increasing amount of inventory so that it is less able to manage its smooth investment and does not create value for the company (Santosa, 2019; Tartilla et al., 2018). However, increased liquidity has the potential to reduce business operational risk due to guaranteed working capital (Horne \& Wachowicz, 2013).

\subsection{Effect leverage on Islamic firm value}

The second hypothesis states that leverage has a significant effect on Islamic firm value. Based on the results of the research conducted, the results obtained leverage coefficient of 3.2663 with a significance value of 0.0029 , indicating that the leverage is positively related and significant to the value of the company, so the hypothesis is accepted. The impact of firm size distribution on leverage has weakened the effect of leverage on firm size. This is due to the negative interaction between longterm debt-equity-total assets that weakens the relationship of leverage with firm size (Cheng \& Tzeng, 2011; Santosa, 2019)

These findings indicate that if the DER has increased, the value of the company will also increase due to the present value of the tax shield, with the target leverage condition not yet exceeded. Also, debt financing encourages business expansion, but if it is excessive, it has the potential to increase financial distress (Brigham \& Houston, 2016). Xin et al. (2019) and Jackson et al. (2013) stated that small leverage is not always better than a large leverage because to achieve the expected level of profit, the company needs debt to grow and expand.

\subsection{Effect of profitability on Islamic firm value}

The third hypothesis shows that profitability has a significant effect on firm value. Based on the results of the research conducted, the regression coefficient results for the ROA variable of 0.2132 with a significance value of 0.0115 , which means profitability has a positive relationship and significantly influences the Islamic firm value, so the hypothesis is accepted. The effect of moderating firm size shows the effect of profitability impact on firm value because the interaction of profitability and firm size has strengthened impact on Islamic firm value (Santosa, 2010; Butar \& Sudarsi, 2012; Dewinta \& Setiawan, 2016).

These findings indicate that if profitability increases, the value of the company will increase, especially if the firm size as a moderating variable also increases. Increased profitability values indicate an increase in management's ability to earn profits so that the company's potential to distribute dividends is increasing (Eldhose \& Kumar, 2019; Kuhlmann \& Rojahn, 2017). 


\subsection{Effect of efficiency on Islamic firm value}

The fourth hypothesis tested produces that efficiency effect on firm value. Based on the results of the research conducted, obtained the coefficient of 2.048 with a significance value of 0.0003 , which means that efficiency has a positive and significant effect on the firm value, so the hypothesis is do not rejected. This finding shows that the management's efficiency determined the value of Islamic firms significantly, especially in managing assets to create revenue (sales). This business dynamism may lead to significant growth of sales. Result presents a positive relationship between firm efficiency and Islamic firm value. This finding is in-line with some previous studies that supported our result (Khaoula \& Moez, 2019; Kasmiati \& Santosa, 2019; Sugiarto \& Santosa, 2018). This suggests that they are controlled by managers who are deemed pursuing opportunistic goals. Therefore, the profit maximization function can be replaced by the utility function of management optimization. The significantly positive relationship between assets turnover and firm value can be explained as the stock market reacts positively to announcements of increased revenues (Santosa, 2019).

\subsection{Influence of audit committee on Islamic firm value}

The audit committee has a role in maintaining the credibility of the financial statement preparation process as well as maintaining the creation of an adequate corporate supervision system and the implementation of good corporate governance (Akinleye et al., 2019). The fifth hypothesis states that the audit committee has a significant effect on firm value positively. Based on the results of the research conducted, the regression coefficient results for the audit committee variable of 0.0522 with a significance value of 0.3273 , which indicates that the audit committee has a positive relationship but does not significantly influence the Islamic firm value, so the hypothesis was rejected. However, the effect of the audit committee becomes significant when the firm size moderates it because each increase in firm size requires an increasingly high audit committee role, both in quantity and quality ( $\mathrm{Ab}$ dul-Majid, 2017; Brick \& Chidambaran, 2010). Corporate governance mechanisms are regarded to be effective normally when there are a high proportion of audit committee members who are independent but not only in just terms of the number of auditors but also the quality of the audit aspects (Abdul-Majid, 2017).

\subsection{Effect of firm size on Islamic firm value}

Another important finding is how firm as size plays an critical role in this study, both as an independent and moderating variable. When firm size as an independent variable (Model 1), the firm size does positive significantly effect on firm value. These findings are in line with the prediction of hypotheses and supported several conclusions from previous studies (Santosa, 2019; Hardian \&
Asyik, 2016; Sayidah, Assagaf, \& Possumah, 2019). According to Brigham and Houston (2016), a positive effect of firm size on Islamic firm value is influenced by the role of the firm size, which is significant in the expansion of the company's business and ease of accessing external capital. Besides, the role of firm size as a moderating variable for liquidity, leverage, profitability, and efficiency strengthens the effect of these variables on firm value, respectively due to the potential for diversification and group business affiliation (Sayidah et al., 2019; Horne \& Wachowicz, 2013; Nurhayati, 2013; Freihat \& Razaq, 2019). However, a lack of information and decision-making problems hinder efficiency at Islamic large companies. In other words, Islamic firm sometimes suffer agency problems.

\subsection{The effect of moderating variable firm size on the relationship between financial characteristic and Islamic firm value}

The effect of the interaction of firm size as moderating and liquidity on Islamic firm value shows strengthens impact so that it was not significant before and be positively moderated $(+0.4452)$ and significant at the $10 \%$ level. The larger the firm's assets, the more substantial liquidity effect on the value of the Islamic firm because observing that firm size will trigger supporting the Islamic firm value as firm size get more massive. These findings are in line with some previous study (Kasmiati \& Santosa, 2019; Nastiti, Atahau, \& Supramono, 2019; Marsha \& Murtaqi, 2017). The role of moderating firm size increases the effect of leverage on firm value which the larger the size the higher the space to increase debt for business expansion. The finding shows that the coefficient on the interaction term between firm size and profitability is very large and positively moderated $(+1.8364)$ and significant at the $5 \%$ level (Bajaj, Kashiramka, \& Singh, 2018; Vătavu, 2015). This result can be explained, among other things, by the finding that consistency between leverage (debt ratio) and Islamic firm value permits managers to engage to add debt financing proportionally.

Moreover, the interaction between firm size and profitability was strengthening the influence of firm value and did not support the company's long-term growth sustainability. The finding shows that the coefficient on the interaction term between firm size and profitability is positively moderated $(+0.1165)$ and significant at the $5 \%$ level. The observation that profitability will trigger the addition of the Islamic firm value, as the firm size gets larger. This result can be regarded, among other things, by the fact that consistency between financial profit and firm value permits management to engage in the investment opportunity (Santosa, 2010; Ding et al., 2014). The last hypothesis is the interaction between firm size and efficiency on firm value. When firm size interacts with an efficiency that proxied by assets turnover, this study finds that the coefficient on the interaction term is positively moderated (+0.0366) and significant at the 5\% level. The role of firm size as a moderating variable strengthens the 
effect of efficiency on firm value because, with increasing company assets are regarded, the efficiency will be higher to create optimal firm value (Santosa, 2019). According to Brigham and Houston (2016), efficiency shows the overall use of company assets in generating a certain level of sales. So with increasing of interaction between efficiency and firm size simultaneously made a bigger impact on firm value, because this interaction indicated that firm size is managed to create sales, effectively (Kasmiati \& Santosa, 2019).

\section{Conclusions}

This study examines the relationship between corporate characteristics, audit committee, and Islamic firm value and explores the moderating effect of firm size on the relationship between main variables of corporate characteristics and Islamic firm value in Indonesia. The overall conclusion is that firm size does appear to play a significant role in determining Islamic firm value. Larger firm size is associated with higher agency costs and less fraud; thus, they believe that the audit committee and firm size can function as an internal corporate governance mechanism and, therefore, increase Islamic firm value.

The findings of this study divide in three ways. First, this study identifies that corporate characteristics as the main independent variables and audit committee as a controlling variable affected Islamic firm value. Second, this study finds evidence of a significant effect of the audit committee on firm value as a controlling variable. Third, the result indicates that firm size as a moderating variable that interacts with corporate characteristics, such as liquidity, leverage, profitability, and efficiency have a significant and positive effect on the relationship between them and Islamic firm value. The results are in-line and consistent with the firm value and agency theory on business sustainability.

The effect of the interaction of firm size as moderating and liquidity on Islamic firm value shows strengthens impact so that it was not significant before and be positively moderated. The larger the firm's assets, the more substantial liquidity effect on the value of the Islamic firm because observing that firm size will trigger increasing the Islamic firm value as firm size get larger. The role of moderating firm size increases the effect of leverage on the firm value, which the larger the size, the higher the space to increase debt for business expansion. The finding shows that the coefficient on the interaction term between firm size and profitability is very large and positively moderated, and the finding that consistency between leverage (debt ratio) and Islamic firm value permits managers to engage to add debt financing proportionally.

Moreover, the interaction between firm size and profitability was strengthening the influence of firm value and did not support the company's long-term growth sustainability. The finding shows that the coefficient on the interaction between firm size and profitability is positively moderated. The observation that profitability will trigger the addition of the Islamic firm value, as the firm size gets larger. This result can be regarded, among other things, by the fact that consistency between financial profit and firm value permits management to engage in the investment opportunity. The last hypothesis is the interaction between firm size and efficiency on firm value. When firm size interacts with an efficiency that proxied by assets turnover, this study finds that the coefficient on the interaction term is positively moderated. The role of firm size as a moderating variable strengthens the effect of efficiency on firm value because, with increasing company assets are regarded, the efficiency will be higher to create optimal firm value. Firm efficiency shows the overall use of company assets in generating a certain level of sales. So with increasing interaction between efficiency and firm size simultaneously made a bigger impact on firm value, because this interaction indicated that firm size is managed to create sales, effectively.

\section{Limitations and avenue for future research}

This study has two limitations, firstly the future model could use re-specification analysis that can capture all data "in-out" to/from the Islamic index along with period study; and secondly, this study could be adding variable control (corporate governance: board of director; independent commissioner; or/and auditor quality) and investment. Besides, it should also consider the use of more extended periods and the comparative study between conventional and Islamic firms in order to obtain more representative findings.

\section{Acknowledgements}

I am very grateful to the editor of Business: Theory and Practices review and reviewers for their valuable suggestions and comments, which led to a significant improvement in the article.

\section{References}

Abdul-Majid, J. (2017). Audit committee independence and a contracting perspective on goodwill impairment: Singaporean evidence. Business: Theory and Practice, 18, 128-135. https://doi.org/10.3846/btp.2017.013

Akinleye, G., Olarewaju, O., \& Fajuyagbe, B. (2019). Corporate governance and financial performance: an empirical analysis of selected multinational firms in Nigeria. Problems and Perspectives in Management, 17(1), 11-18. https://doi.org/10.21511/ppm.17(1).2019.02

Alamanda, Y., \& Santosa, P. W. (2013). Growth Value Metric PT Summarecon Agung, Tbk pada Sektor Properti di Bursa Efek Indonesia. Jurnal Manajemen IBII, 2(2), 202-217.

Apan, M., \& İslamoğlu, M. (2018). Determining the impact of financial characteristics on firm profitability: An empirical analysis on borsa Istanbul energy firms. WSEAS Transactions on Business and Economics, 15, 547-559.

Bajaj, Y., Kashiramka, S., \& Singh, S. (2018). Dynamics of capital structure: evidence from Indian manufacturing firms. J. for Global Business Advancement, 11(6), 667.

https://doi.org/10.1504/JGBA.2018.097774 
Balagobei, S. (2018). Corporate governance and firm performance: Empirical evidence from emerging market. Asian Economic and Financial Review, 8(12), 1415-1421. https://doi.org/10.18488/journal.aefr.2018.812.1415.1421

Brick, I. E., \& Chidambaran, N. K. (2010). Board meetings, committee structure, and firm value. Journal of Corporate Finance, 16(4), 533-553. https://doi.org/10.1016/j.jcorpfin.2010.06.003

Brigham, E. F., \& Houston, J. F. (2016). Fundamentals of Financial Management (14th ed.). Cengage.

Butar, L. K. B., \& Sudarsi, S. (2012). Pengaruh Ukuran Perusahaan, Profitabilitas, Leverage, dan Kepemilikan Institusional terhadap Perataan Laba. Strategic Direction, 29(1), 12-15. https://doi.org/10.1108/02580541311285366

Carter, D. A., Simkins, B. J., \& Simpson, W. G. (2003). Corporate governance, board diversity, and firm value. Financial Review, 38(138), 33-53. https://doi.org/10.1111/1540-6288.00034

Cheng, M.-C., \& Tzeng, Z.-C. (2011). The effect of leverage on firm value and how the firm financial quality influence on this effect. World Journal of Management, 3(2), 30-53.

Černius, G., \& Birškyte, L. (2020). Financial Information and Management Decision: Impact of Accounting Policy on Financial Indicators of the Firm. Business: Theory and Practice, 21(1), 48-57. https://doi.org/10.3846/btp.2020.9959

Dewinta, I. A. R., \& Setiawan, P. E. (2016). Pengaruh Ukuran Perusahaan, Umur Perusahaan, Profitabilitas, Leverage, Dan Pertumbuhan Penjualan Terhadap Tax Avoidance. E-Jurnal Akuntansi, 14(3), 1584-1615.

Ding, C. G., Wang, H.-J., Lee, M.-C., Hung, W.-C., \& Lin, C.-P. (2014). How does the change in investor sentiment over time affect stock returns? Emerging Markets Finance and Trade, 50(sup2), 144-158.

https://doi.org/10.2753/REE1540-496X5002S210

Eldhose, K. V., \& Santhosh Kumar, S. (2019). Determinants of financial leverage: an empirical analysis of manufacturing companies in India. Indian Journal of Finance, 13(7), 41. https://doi.org/10.17010/ijf/2019/v13i7/145534

Febriawan, M., \& Santosa, P. W. (2018). Return Saham dan Faktor Fundamental pada Pra Krisis Ekonomi Global 2008 di Bursa Efek Indonesia. Journal of Economics and Business Aseanomics, 2(2), 232-248.

Freihat, F., \& Razaq, A. (2019). Factors affecting price to earnings ratio $(\mathrm{P} / \mathrm{E})$ : Evidence from the emerging market. Risk Governance and Control: Financial Markets and Institutions, 9(2), 47-56. https://doi.org/10.22495/rgcv9i2p4

Gujarati, D. N., \& Porter, D. C. (2013). Basic econometrics. In International Edition (Fourth). McGraw-Hill/Irwin.

Hardian, A. P., \& Asyik, N. F. (2016). Kinerja Keuangan dan Ukuran Perusahaan Terhadap Nilai Perusahaan, CSR Sebagai Variabel Moderasi. Jurnal Ilmu \& Riset Akuntansi, 5(9), 1-16.

Hermawan, A. A. (2011). The influence of effective board of commissioners and audit committee on the informativeness of earnings: evidence from Indonesian listed firms. Asia $\mathrm{Pa}$ cific Journal of Accounting and Finance. https://www.mendeley.com/catalogue/397da15e-7e32-3fbe-a579-041499d29d1d/

Hunjra, A. I. (2018). Mediating role of dividend policy among its determinants and organizational financial performance. Cogent Economics and Finance, 6(1), 1-16. https://doi.org/10.1080/23322039.2018.1558714

Indonesia Stock Exchange. (2018). ISSI Stock Index 2014-2018. https://www.idx.co.id/en-us/market-data/stocks-data/stockindex/

Jackson, S. B., Keune, T. M., \& Salzsieder, L. (2013). Debt, equity, and capital investment. Journal of Accounting and Economics, 56(2-3), 291-310.

https://doi.org/10.1016/j.jacceco.2013.09.001
Johan, S., Siregar, H., Maulana, T. N. A., \& Santosa, P. W. (2012). Key financials performance independent versus integrated: empirical evidence from Indonesia financial service industry (2001-2011). International Journal of Economics and Finance, 5(1), 92-104. https://doi.org/10.5539/ijef.v5n1p92

Kasmiati, M., \& Santosa, P. W. (2019). The effect of earning information, cash flow componens, firnancing decision, and stock return: empirical evidence on Indonesia stock exchange. Journal of Economics, Business \& Accountancy Ventura, 22(2), 157-166. https://doi.org/10.14414/jebav.v22i2.1638

Khaoula, F., \& Moez, D. (2019). The moderating effect of the board of directors on firm value and tax planning: Evidence from European listed firms. Borsa Istanbul Review, 19(4), 331-343. https://doi.org/10.1016/j.bir.2019.07.005

Kuhlmann, S., \& Rojahn, J. (2017). The impact of ownership concentration and shareholder identity on dividend payout probabilities: New evidence from the German stock market. Corporate Ownership and Control, 15(1), 18-32. https://doi.org/10.22495/cocv15ilart2

Laily, N. (2017). The effects of good corporate governance and audit quality on earnings management. Journal of Accounting and Business Education, 1(1), 134-143. https://doi. org/10.26675/jabe.v1i1.9754

Marsha, N., \& Murtaqi, I. (2017). The effect of financial ratios on firm value in the food and beverage sector of the IDX. Journal of Business and Management, 6(2), 214-226.

Masdupi, E., Tasman, A., \& Davista, A. (2018). The influence of liquidity, leverage and profitability on financial distress of listed manufacturing companies in Indonesia. Advances in Economics, Business and Management Research, 57(Piceeba), 223-228. https://doi.org/10.2991/piceeba-18.2018.51

Mukhtaruddin, M., Ubaidillah, U., Dewi, K., Hakiki, A., \& Nopriyanto, N. (2019). Good corporate governance, corporate social responsibility, firm value, and financial performance as moderating variable. Indonesian Journal of Sustainability Accounting and Management, 3(1), 55. https://doi.org/10.28992/ijsam.v3i1.74

Nanik, L., \& Candra, S. R. (2016). Pengaruh Intellectual Capital Terhadap Nilai Perusahaan. Jurnal Akuntansi, Ekonomi Dan Manajemen Bisnis, 4(1), 28-33.

Nastiti, P. K. Y., Atahau, A. D. R., \& Supramono, S. (2019). The determinants of working capital management: the contextual role of enterprise size and enterprise age. Business, Management and Education, 17(2), 94-110.

https://doi.org/10.3846/bme.2019.10409

Nguyen, V. C., Nguyen, T. N. L., Tran, T. T. P., \& Nghiem, T. T. (2019). The impact of financial leverage on the profitability of real estate companies: A study from Vietnam stock exchange. Management Science Letters, 9(Spceial Issue 13), 2315-2326. https://doi.org/10.5267/j.msl.2019.7.023

Nurhayati, M. (2013). Profitabilitas, likuiditas dan ukuran perusahaan pengaruhnya terhadap kebijkan dividen dan nilai perusahaan sektor non jasa. Jurnal Keuangan Dan Bisnis, 5(2), 144-153.

Nurlela, N., Sulastri, S., Hamdan, U., \& Hanafi, A. (2019). The influence of investment decisions and financing decisions on firm value with profitability as intervening variables (empirical study on companies listed in Indonesian Sharia Stock Index). International Journal of Multicultural and Multireligious Understanding, 6(2), 447-456. https://doi.org/10.18415/ijmmu.v6i2.758

Paul, S. Y., Guermat, C., \& Devi, S. (2018). Why do firms invest in accounts receivable? An empirical investigation of the Malaysian manufacturing sector. Journal of Accounting in Emerging Economies, 8(2), 166-184.

https://doi.org/10.1108/JAEE-01-2017-0005 
Prieto, A. B. T., \& Lee, Y. (2019). Internal and external determinants of capital structure in Large Korean Firms. Global Business and Finance Review, 24(3), 79-96. https://doi.org/10.17549/gbfr.2019.24.3.79

Rehman, O. U. (2016). Impact of Capital structure and dividend policy on firm value. Journal of Poverty, Investment and Development, 21(2), 308-324.

Ross, S. A., Westerfield, R. W., \& Jordan, B. D. (2013). Fundamentals of corporate finance (10th). McGraw-Hill/Irwin.

Santosa, P. W. (2010). Longterm performance trends analysis and managing expectation for active value (Case study PT Indocement Tunggal Prakarsa, Tbk). Finance \& Accounting Journal, 12(02), 94-101.

Santosa, P. W. (2019). Financial performance, exchange rate and stock return: evidence from manufacturing sector. Jurnal Manajemen Teknologi, 18(3), 205-217. https://doi.org/10.12695/jmt.2019.18.3.5

Santosa, P. W. (2020). Determinants of price reversal in highfrequency trading: empirical evidence from Indonesia. Investment Management and Financial Innovations, 17(1), 175-187. https://doi.org/10.21511/imfi.17(1).2020.16

Santosa, P. W., \& Hidayat, A. (2014). Riset Terapan: Teori dan Aplikasi (1rst edit). Globalstat Solusi Utama.

Santosa, P. W., \& Laksana, H. Y. (2011). Value at risk, market risk and trading activity: CAPM Alternative Model. Journal of Applied Finance \& Banking, 1(4), 239-268.

Sayidah, N., Assagaf, A., \& Possumah, B. T. (2019). Determinant of state-owned enterprises financial health: Indonesia empirical evidence. Cogent Business and Management, 6(1), 1-15. https://doi.org/10.1080/23311975.2019.1600207

Shao, L. (2019). Dynamic study of corporate governance structure and firm performance in China. Chinese Management Studies, 13(2), 299-317. https://doi.org/10.1108/CMS-08-2017-0217

Subramanyam, K. R. (2014). Financial statement analysis (eleventh). McGraw-Hill/Irwin.

Sugiarto, M., \& Santosa, P. W. (2018). Pengaruh Indikator Makroekonomi, Kinerja Keuangan, dan Tata Kelola Terhadap Nilai Perusahaan Pada Sektor Properti di Bursa Efek Indonesia. Journal of Economics and Business Aseanomics, 2(2), 288-312.

Sutriani, A. (2014). Pengaruh Profitabilitas, Leverage, dan Likuiditas terhadap Return Saham dengan Nilai Tukar ebagai
Variabel Moderasi pada Saham LQ-45. Journal of Business and Banking, 4(1), 67-80. https://doi.org/10.14414/jbb.v4i1.294

Suwardika, I. N., \& Mustanda, I. K. (2017). Pengaruh Leverage, Ukuran Perusahaan, Pertumbuhan Perusahaan dan Profitabilitas terhadap Nilai Perusahaan (Perusahaan Properti yang terdaftar Di Bursa Efek Indonesia). E-Jurnal Manajemen Universitas Udayana, 6(3), 1248-1277.

Tambunan, M., Siregar, H., Manurung, A., \& Priyarsono, D. (2017). Related party transactions and firm value in the business groups in the Indonesia stock exchange. Journal of Applied Finance \& Banking, 7(3), 1-20. https://search.proquest. com/abicomplete/docview/1898416706/fulltextPDF/7011AC E8BAF9440BPQ/38? accountid=151027

Tartilla, N., Darmansyah, D., \& Anwar, C. (2018). Determinan Nilai Perusahaan Dengan Transparansi Informasi Sebagai Pemoderasi. Liquidity, 5(2), 107-117. https://doi. org/10.32546/lq.v5i2.51

Thaharah \& Asyik. (2016). Pengaruh Mekanisme Corporate Governance Dan Kinerja Keuangan Terhadap Nilai Perusahaan LQ 45. Jurnal Ilmu Dan Riset Akuntansi.

Tuan, N. Van, \& Tuan, N. A. (2016). Corporate governance structures and performance of firms in Asian markets: a comparative analysis between Singapore and Vietnam. Organizations and Markets in Emerging Economies, 7(2), 112-140. https://doi.org/10.15388/omee.2016.7.2.14210

Utami, P., \& Welas, W. (2019). Pengaruh Current Ratio, Return On Asset, Total Asset Turnover Dan Debt To Equity Ratio Terhadap Nilai Perusahaan. Jurnal Akuntansi Dan Keuangan, $8(1), 57-76$.

Vătavu, S. (2015). The impact of capital structure on financial performance in Romanian listed companies. Procedia Economics and Finance, 32, 1314-1322. https://doi.org/10.1016/S2212-5671(15)01508-7

Widyastuti, M. (2019). Analysis of liquidity, activity, leverage, financial performance and company value in food and beverage companies listed on the Indonesia Stock Exchange. International Journal of Economics and Management Studies, 6(5), 52-58. https://doi.org/10.14445/23939125/IJEMS-V6I5P109

Xin, K., Sun, Y., Zhang, R., \& Liu, X. (2019). Debt financing and technological innovation: Evidence from China. Journal of Business Economics and Management, 20(5), 841-859. https://doi.org/10.3846/jbem.2019.10185 